\title{
Inhalt Band 37
}

L. Hofranan, Monika Klein und R. Schimmann, Untersuchungen an Ratten zur Nährstoffabhängigkeit des Energieerhaltungsbedarfs. 4. Mitt. : Der Einfluß des Proteinniveaus der Nahrung auf den Energieerhaltungsbedarf von Ratten im Verlauf des Wachstums und nach Abschluß der intensiven Wachstumsphase . . . . . . . . . . . . . . .

M. Оtтo, MAJA ŠnejdáRKová and K. Bō̌A, Quantification of lysine dynamics in the Japanese quail . . . . . . . . . . . . . . . . . . . . . . . . . . . . . . . .

Buchbesprechung . . . . . . . . . . . . . . . . . . . . . . . . .

H. Bergner, Nguyen Thi Nhan und Annette Wilke, Methodische Untersuchungen zur stoffwechselorientierten Lysinbedarfsbestimmung an Broilerküken. 1. Mitt.: Einfluß des Lysingehaltes der Diät auf die Lysin-Oxydationsrate bei kurzzeitigem Futterentzug vor der ${ }^{14} \mathrm{C}$-Lysininjektion . . . . . . . . . . . . . . . . . . . . . . . . . .

K. GruHn, Zur Verwertung von ${ }^{15} \mathrm{~N}$-markiertem Harnstoff bei der Legehenne. 7. Mitt.: ${ }^{15} \mathrm{~N}$ Inkorporation in die Aminosäuren verschiedener Muskelarten . . . . . . . . . . .

J. Voigt and B. Pratkowski, Ruminal protein degradation and protein value of feeds . .

S. Legel, M. HoffMann und G. P. Gongnet, Untersuchungen zur Wirkung einer reduzierten Tränkwassergabe auf die Futteraufnahme, die scheinbare Verdaulichkeit von Rohnährstoffen und die Pansenfermentation bei Schafen . . . . . . . . . . . . . . . .

A. Dittrich, Christina Sacher, D. Prediger und M. Hoffmann, Untersuchungen zum Verzehrs- und Wiederkauverhalten an Schafen. 3. Mitt.: Versuche an güsten Mutterschafen verschiedener Rassen unter Berücksichtigung von Rationstyp und Fütterungsdauer . . . . . . . . . . . . . . . . . . . . . . . . . . .

Aniela Falkowska and Stefania Iwańska, The effect of "Ferrodex", vitamin A and "Rovimıx $\beta$-carotene" on the iron and copper levels in blood plasma of calves . . . . .

W. StefFens, Verwendung von Geflügelabfallmehl zum vollständigen Fischmehlersatz im Forellenbrut- und -aufzuchtfutter

Prof. Dr. Berinhard Piatkowski zum 60. Geburtstag am 5. 2.1987 . . . . . . . . . . 105 
Nguyen Thi Nhan, Annetre Wilke und H. Bergner, Methodische Untersuchungen zur stoffwechselorientierten Lysinbedarfsbestimmung an Broilerküken. 2. Mitt.: Einfluß des Lysingehaltes der Diät auf die Lysin-Oxydationsrate bei 15stündigem Futterentzug vor der ${ }^{14}$ C-Lysininjektion . . . . . . . . . . . . . . . . . . . .

K. GruHn und Herta Graf, Zur Verwertung von ${ }^{15} \mathrm{~N}$-markiertem Harnstoff bei der Legehenne. 8. Mitt.: ${ }^{15} \mathrm{~N}$-Inkorporation in die Aminosäuren des Oviduktes . . . . . . . .

K. GruHn, Zur Verwertung von ${ }^{15} \mathrm{~N}$-markiertem Harnstoff bei der Legehenne. 9. Mitt.: Knochen, Federn und ${ }^{15} \mathrm{~N}$-Inkorporation im Restkörper . . . . . . . . . . . .

R. ZANDER und K. GruHN, Die Verwertung des Rohproteins von ${ }^{15} \mathrm{~N}$-markiertem Stroh durch Broilerzuchthennen . . . . . . . . . . . . . . . . . . .

Rosemarie Jacob-Hammermann, M. Kirchgessner und H.-P. Roth, Zum Einfluß einer hinsichtlich Qualität und Quantität unterschiedlichen Proteinversorgung auf Wachstum und Wachstumshormon im Serum entwöhnter Ratten . . . . . . . . . . . . . .

F. Liebert und G. Gebhardt, Ergebnisse zur Wirksamkeit und zum Bedarf an ausgewählten Aminosäuren beim wachsenden weiblichen Schwein. 2. Mitt.: Methionin und Zystin

J. WÜnsche, Marlis Meint, U. Hennig, Edda Borgmann, F. Kretengring und H.-D. Bock, Einfluß einer thermischen Behandlung von Kartoffelprodukten auf den Nährstoffabbau im Verdauungstrakt des Schweines. 1. Mitt.: Passage und Verdaulichkeit der Nährstoffe in den verschiedenen Darmabschnitten . . . . . . . . . . . . .

L. Hoffmann, Auswirkungen von Ernährungs- und Haltungsfaktoren auf die Wärmeproduktion von Ratten und Broilern. 1. Mitt.: Wärmeproduktion wachsender Broilerküken bei Haltung in Gruppen in Abhängigkeit von der Umgebungstemperatur . . . . . .

M. Valdivie und S. Poppe, Untersuchungen zur Energie- und Proteinkonzentration von Broilerrationen in Kuba. 2. Mitt.: Weibliche Broiler im Winter . . . . . . . . . .

R. ZANDER, K. GRUHN und A. Hennig, Der Einfluß von Strohmehl auf den Rohprotein- und Aminosäurenstoffwechsel und die Verdaulichkeit der Rohnährstoffe bei Broilerzuchthennen. 1. Mitt.: Problemstellung, Versuchsübersicht, N-Ausscheidung über den Harn

R. Fuchs, Helga Miltitz und M. Hoffmann, Untersuchungen zur Verdaulichkeit der Rohnährstoffe bei Pferden. 1. Mitt.: Methoden zur Bestimmung der Verdaulichkeit . . .

W. I. Ochrimenko, G: Flachowsky, G. Richter und A. Hennig, Untersuchungen zum Einsatz von unterschiedlich behandeltem Weizenstroh in der Mastrinderfütterung unter besonderer Berücksichtigung von mit Harnstoff konserviertem Feuchtstroh. 2. Mitt.: Mast- und Schlachtergebnisse bei ad-libitum-Fütterung . . . . . . . . . . . .

J. Vetrer und E. Haraszti, Gehalt an Trypsininhibitoren in den Körnern von Getreidearten und Hülsenfrüchten. . . . . . . . . . . . . . . . . . . . .

M. Anke, B. Groppel, S. Szentminalyi†, M. Grün und Hella Kronemann, Der Kupfergehalt der Flora in Abhängigkeit vom Alter, von der geologischen Herkunft des Standortes und der Pflanzenart. . . . . . . . . . . . . . . . . . .

Annette Wiuke, H. Bergner und Nguxen Thi Nhas, Methodische Untersuchungen zur stoffwechselorientierten Methioninbedarfsbestimmung an Broilerküken. 1. Mitt.: Ausscheidung von ${ }^{5} \mathrm{~S}$ in den Exkrementen nach ${ }^{35} \mathrm{~S}$-Methionin-Injektion bei gestaffelter Methioningabe ................. 
Buchbesprechung . . . . . . . . . . . . . . . . . . . . . . . .

A. Hennig, K. Gruhn und E. Kirchner, Dynamik des Aminosäuren- und Proteinstoffwechsels der Legehennen nach Applikation von ${ }^{15} \mathrm{~N}$-markiertem Weizenprotein. 1. Mitt.: Problemstellung, Versuchsprogramm und ${ }^{15} \mathrm{~N}$-Markierung des Harnes . . . . :

R. ZANDER und K. GRuHn, Der Einfluß von Strohmehl auf den Rohprotein- und Aminosäurenstoffwechsel und die Verdaulichkeit der Rohnährstoffe bei Broilerzuchthennen. 2. Mitt.: Verdaulichkeit der Rohnährstoffe der Rationen und des ${ }^{15} \mathrm{~N}$ aus Strohmehl und Weizen..............................

E. Toncheva, Y. Profirov and R. Voynova, Disaccharidase activity in intestine epithelium Microvilli membranes of lambs during the first month after birth . . . . . . .

Anna M. Denholm and J. R. Lrng, Whole animal and rumen digestive parameters of sheep given a concentrate diet supplemented with sodium bicarbonate . . . . . . . . . .

G. Burlacu, M. Nicolae and R. Burlacu, Feeding value of corn and corn silage fed at different levels in the diets for young cattle . . . . . . . . . . . . . . . . .

Buchbesprechung . . . . . . . . . . . . . . . . . . . . . . . . . . .

M. Hoffmann, O. Steinhöfel und R. Fuchs, Untersuchungen zur Verdaulichkeit der Rohnährstoffe bei Pferden. 2. Mitt.: Vergleichende Untersuchungen zum Verdauungsvermögen von Warmblutpferd, Pony und Hammel . . . . . . . . . . . . . . . . .

GISEla RüCKer und O. KNaBe, Trockensubstanzverluste und Qualitätsveränderungen beim Welken von Gras. 3. Mitt. : Einfluß der Mähgutaufbereitung . . . . . . . . . . .

S. Legel, A. A. Rukantabula und C. Geissler, Untersuchungen zur Beeinflussung des Rohnährstoffgehaltes von Futtermitteln tropischer Regionen während der Lagerung unter extremen Klimabedingungen. 1. Mitt.: Wirkung unter humiden konstanten Klimabedingungen

Buchbesprechung . . . . . . . . . . . . . . . . . . . . . . . . .

Buchbesprechung

L. Hoffmann und Monika Klein, Auswirkungen von Ernährungs- und Haltungsfaktoren auf die Wärmeproduktion von Ratten und Broilern. 2. Mitt.: Einfluß der Umgebungstemperatur auf die Wärmeproduktion ausgewachsener Broiler und Ratten . . . . .

Buchbesprechung . . . . . . . . . . . . . . . . . . . . . . . . . . . .

F. Liebert, H. Le Khac und G. Gebhardt, Ergebnisse zur Wirksamkeit und zum Bedarf an ausgewählten Aminosäuren beim wachsenden weiblichen Schwein. 3. Mitt. : Threonin

M. Valdrvié und S. Poppe, Untersuchungen zur Energie- und Proteinkonzentration von Broilerrationen in Kuba. 3. Mitt.: Männliche Broiler im Sommer . . . . . . . . . .

Buchbesprechung . . . . . . . . . . . . . . . . . . . . . . . . . . .

G. Richter, B. Meixner, K. Gruhn, H. Reinert und R. Abend, Vergleichende Prüfung verschiedener Futterhefen bei Legehennen und Broilern . . . . . . . . . . . . .

K. Zimmermann und J. v. Lengerken, Zur objektiven Beurteilung von Resultaten aus Ringversuchen. 1. Mitt.: Kritische Bestandsaufnahme . . . . . . . . . . . . . . 
Workshop zu Problemen der Verdauungsphysiologie beim Wiederkäuer (Rostock, 16.17. 1. 1986) . . . . . . . . . . . . . . . . . . . . .

H. Priebs, Doris Thomaneck und T. Heinz, Bestimmung der scheinbaren Verdaulichkeit des Rohproteins beim Hühnergeflügel mit Hilfe der $\alpha-\mathrm{NH}_{2}$-N-Methode . . . . . . .

R. J. Merry, R. H. Smith and A. B. McAllax, Studies of rumen function in an in vitro continous culture system ................

M. KreUZer und M. KirChgessner, Untersuchungen zur nutritiven Defaunierung des Pansens beim Wiederkäuer . . . . . . . . . . . . . . . . .

Buchbesprechung .......................

K. GRUHN und G. JAHREIs, Dynamik des Aminosäuren- und Proteinstoffwechsels der Legehennen nach Applikation von ${ }^{15} \mathrm{~N}$-markiertem Weizenprotein. 2. Mitt.: ${ }^{15} \mathrm{~N}$-Exkretion mit dem Stickstoff und den basischen Aminosäuren des Kotes . . . . . . . . . . .

M. Valdivie und S. Poppe, Untersuchungen zur Energie- und Proteinkonzentration von Broilerrationen in Kuba. 4. Mitt.: Weibliche Broiler im Sommer . . . . . . . . . .

Maria KreEowsKa-Kueas, The effect of krill meal at lowered chitin contents in feed mixtures for fattening pigs on depot fat quality . . . . . . . . . . . . . . . .

Sigrun Souffrant, H. Jeroch und W. RötSChke, Futterwert von Grünmais in Hauptfruchtstellung . . . . . . . . . . . . . . . . . . .

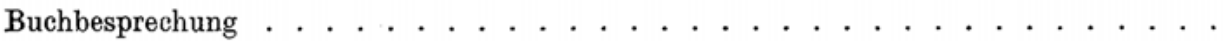

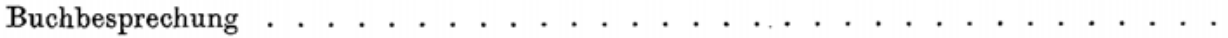

K. D. Wutzke, Tamara P. Zhukova, Elena G. Sorokina, C. Plath, I. Richter, W. Heine und M. FrIEDRICH, Untersuchungen zur Dosisabhängigkeit der ${ }^{15} \mathrm{~N}$-Inkorporation in Organproteine neugeborener Ratten nach Pulsmarkierung mit verschiedenen Tracern .

F. Liebert, H. Le Khac und G. Gebhardt, Ergebnisse zur Wirksamkeit und zum Bedarf an ausgewählten Aminosäuren beim wachsenden weiblichen Schwein. 4. Mitt.: Kombinationen von Proteinträgern mit Lysin-, Methionin/Zystin- bzw. Threoninlimitanz . .

Marlis Meinl, J. Wünsche, U. Hennig und Traude Vö́lker, Einfluß einer thermischen Behandlung von Kartoffelprodukten auf den Nährstoffabbau im Verdauungstrakt des Schweines. 2. Mitt.: Gehalte an Nährstoffen sowie Bakterientätigkeit in den verschiedenen Darmabschnitten . . . . . . . . . . . . . . . . .

C. WECKE, H. Jeroch und G. GEBHARDT, Zum Futterwert und Einsatz von CCM-Silagen bei Mastschweinen unter besonderer Berücksichtigung von CCM-Silage aus einer lysinreichen Maismutante und einer Mischsilage aus CCM und Luzerneblatt. 1. Mitt.: Silagequalität, N-Bilanz- und Verdauungsversuche . . . . . . . . . . . . .

H. HäGER, H. MÜNCHOw, B. ILGNER und W. BUSCH, Untersuchungen zum Einsatz von teilhydrolysiertem und unbehandeltem Strohmehl in der Fütterung von' Zuchtsauen. 4. Mitt.: Einfluß auf die embryonale Mortalität und Fruchtbarkeitsleistung . . . . .

K. GrUHN und E. KrRCHNER, Dynamik des Aminosäuren- und Proteinstoffwechsels der Legehennen nach Applikation von ${ }^{15} \mathrm{~N}$-markiertem 'Weizenprotein. 3. Mitt.: Inkorporation des ${ }^{15} \mathrm{~N}$ in die Eischale, das Eiklar und das Eidotter . . . . . . . . . . . . . . . 
K. GRUHN und R. ZANDer, Dynamik des Aminosäuren- und Proteinstoffwechsels der Legehennen nach Applikation von ${ }^{15} \mathrm{~N}$-markiertem Weizenprotein. 4. Mitt.: ${ }^{15} \mathrm{~N}$-Inkorporation in die Aminosäuren der Eifraktionen . . . . . . . . . . . . . . . . . . . . . .

K. Gruhn und R. Zander, Der Einfluß von Strohmehl auf den Rohprotein- und Aminosäurenstoffwechsel und die Verdaulichkeit der Rohnährstoffe bei Broilerzuchthennen.

3. Mitt.: Verdaulichkeit der Aminosäuren . . . . . . . . . . . . . . . . . .

M. Barax and V. KMEŤ, Effect of pectinase on rumen fermentation in sheep and lambs . .

M. Ulbrich, Ramona Eibicht, Ch. Geissler, E. Boldt und M. Hoffmaxi, Einfluß von Emulgatoren und Fettmischungen auf die Verdaulichkeit und den Ansatz von Fett-

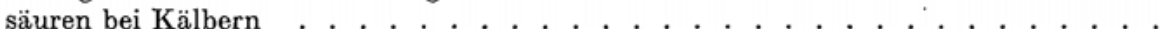

G. Burlacu, M. Nicolae, P. Cărămidă and R. Petrescu, The comparative efficiency of feed utilization in Merino, Turcana and Karakoul sheep . . . . . . . . . . . . . . . .

A. L. Jones and A. L. Goetsch, Effects of dietary forage proportion on digestive function in maintenance-fed beef cows. 1. Fescue and clover hays . . . . . . . . . . .

A. L. Jones, A. L. Goetsch and S. R. Stokes, Effects of dietary forage proportion on digestive function in maintenance-fed beef'cows. 2. Fescue and bermudagrass hays . .

Zuzana Čerešñáxová, Maria Chrenková, A. Sonimer and P. Fl'ak, Study of changes of properties in thermically and hydrothermically treated feeds. 2 . N fractions in fermentation medium at the incubation of treated feeds under in vitro conditions . . . . . .

K. Zimmermane und J. v. Lengerken, Zur objektiven Beurteilung von Resultaten aus Ringversuchen. 2. Mitt.: Anwendung erweiterter Modelle . . . . . . . . . . . . .

T. Pahle, Rosemarie Köhler und G. Gebhardt, Methodische Aspekte zur Bestimmung von N-Umsatzparametern aus ${ }^{15} \mathrm{~N}$-Tracerversuchen an Schweinen auf der Grundlage von Modellen des N-Stoff wechsels. 3. Mitt.: Berechnung von Proteinsynthese und -zerfallsraten auf der Basis des Lysin-Fluxes, ermittelt aus den ${ }^{15} \mathrm{~N}$-Mengen im Harn . . . . .

J. Wünsche, U. Herrmann, Marlis Meinl, U. Hennig, F. Kreienbring und P. Zwierz, Einfluß exogener Faktoren auf die präzäkale Nährstoff- und Aminosäurenresorption, ermittelt an Schweinen mit Ileo-Rektal-Anastomosen. 1. Mitt.: Einfluß des Zerkleinerungsgrades von Getreide . . . . . . . . . . . . . . . . . .

K. Gruhn, R. Zander und E. Krrchner, Dynamik des Aminosäuren- und Proteinstoffwechsels der Legehennen nach Applikation von ${ }^{15} \mathrm{~N}$-markiertem Weizenprotein. 5. Mitt.: Inkorporation des ${ }^{15} \mathrm{~N}$ in die Blutfraktion und deren Aminosäuren . . . . . . . . .

M. Ulbrich, E. Boldt, K. Richter und Marei Torzewski, Vergleich von Schmalz-TalgGemisch und Knochenfett im Verdauungs- und Wachstumsversuch mit Kälbern . .

A. B. Mcallan, Patricia E. Lewis and E. S. Griffith, The effects of frequency of feeding on some quantitative aspects of digestion in the rumens of growing steers . . . . . .

M. Vermorel, J. P. DULPHY and J. C. Bouvier, Energy utilization of sodium hydroxide treated or untreated straw supplemented with protein or concentrates by adult sheep. 1. Feed intake, digestibility, metabolizability an net energy value . . . . . . . 
J. P. DULPHy, E. GRENeT and M. Vermorel, Energy utilization of sodium hydroxide treated or untreated straw supplementted with protein or concentrates by adult sheep.

2. Rumen digestion

K.-D. Robowsky, O. Knabe und H. Seyfarth, Untersuchungen zum Perlolingehalt in Futtergräsern. 1. Mitt.: Die quantitative Bestimmung des Perlolins . . . . . . . .

K.-D. Robowsky, O. Knabe und K. Netzband, Untersuchungen zum Perlolingehalt in Futtergräsern. 2. Mitt.: Perlolingehalt in ausgewählten Grasarten und seine Variabilität im Rohrschwingel und intergenerischen Rohrschwingelbastarden . . . . . . . .

O. Simon, H. Bergener and I. G. PARtridge, Estimation of the endogenous N proportions in ileal digesta and faeces in ${ }^{15} \mathrm{~N}$-labelled pigs . . . . . . . . . . . . . .

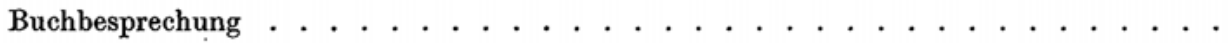

Lucyna Buraczewska, E. Schulz and Harriet Schröder, Ileal digestibility of amino acids in pigs fed barleys differing in protein content . . . . . . . . . . .

G. Thorbek, S. Hencked, A. Chwalibog and B. O. EgGum, Studies on nitrogen retention in growing pigs . . . . . . . . . . . . . . . .

J.F.Agunlera and C. Prieto, Effects of protein quality on energy requirements for maintenance in growing rats . . . . . . . . . . . .

S. Legel und A. A. Rukantabula, Untersuchungen zur Beeinflussung des Rohnährstoffgehaltes von Futtermitteln tropischer Regionen während der Lagerung unter extremen Klimabedingungen. 2. Mitt.: Wirkung unter ariden wechselnden Klimabedingungen . .

Jahrestagung der Gesellschaft für Ernährung in der DDR, Sektion Tierernährung, vom 1.3. Oktober 1986 in Neubrandenburg (Kurzreferate) . . . . . . . . . .

R. Schiemann, W. Jentsch, L. Hoffmann und Hildegard Wittendurg, Untersuchungen zum Energiebedarf weiblicher Jungrinder. 1. Mitt.: Versuchsübersicht und Lebendmasseentwicklung der Tiere . . . . . . . . . . . . . . . .

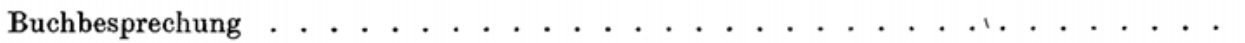

R. Schimana, W. Jentsch und L. Hoffmann, Untersuchungen zum Energiebedarf weiblicher Jungrinder. 2. Mitt.: Stoff- und Energieumsatz . . . . . . . . . . . .

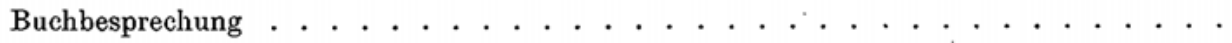

Brigitta Kirsche, M. Schlenzig, W. I. Ochrimenko and G. Flachowsky, Influence of $\beta$ carotene supplementation on carotene content of ovaries of heifers . . . . . . . .

K. KošŤA, DoRota KošŤová, P. REHÁK and K. BoD̆A, Electrophysiological characteristic of the ventromedial hypothalamic nucleus and lateral hypothalamic area in normally fed and 24 hour food deprived conscious sheep . . . . . . . . . . . . 1001

A. L. Jones, A. L. Goersch, S. R. Stokes and M. Colberg, Effects of dietary forage proportion on digestive function in maintenance-fed beef cows. 3. Bermudagrass and clover hays

H. J. Oslage, F. E. Farries und H. Fliegel, Über die Exaktheit von Stickstoffbilanzen bei langfristigen Stoffwechselversuchen . . . . . . . . . . . 1021 
G. Richter, Annelore Lemser, G. Jahreis und G. Steinbach, Untersuchungen zum Vitamin-E-Bedarf der Küken und Junghennen . . . . . . . . . . . . . . . . . 1029

K. Krawielitzki, Ruthrld Schaderert und J. Wünsche, Kinetische Parameter des Proteinstoffwechsels der Ratte bei proteinfreier Ernährung . . . . . . . . . . . . 1041

W. JENTSCH, Untersuchungen zum Energiebedarf weiblicher Jungrinder. 3. Mitt.: Reproduktion und Konzeptionsprodukte . . . . . . . . . . . . . . . . . . . . . .

J. Marienbutrg, R. Görsch und H. Bergner, Einfluß der physikalischen Eigenschaften von Strohpellets auf deren Verdaulichkeit und die Passagerate von $\mathrm{Cr}_{2} \mathrm{O}_{3}$ bei Schafen .

A. L. Goetsch and F. N. Owens, Effects of supplement sulfate (Dynamate ${ }^{R}$ ) and thiamin$\mathrm{HCl}$ on passage of thiamin to the duodenum and site of digestion in steers . . . . . .

K. Krawieltizkr, Ruthild Schaderetr, Edda Borgmann und Brigitta Evers, Prüfung von ${ }^{51} \mathrm{Cr}_{2} \mathrm{O}_{3}$ und $\mathrm{TiO}_{2}$ als Marker für die Bestimmung von Passagerate und Proteinverdaulichkeit bei Ratten . . . . . . . . . . . . . . . . . . . . . .

R. BĘZA, Studies on nitrogen metabolism in rats of different age fed on a protein-free diet. 3 . Urinary endogenous nitrogen excretion in relation to body size and protein-free feeding duration . . . . . . . . . . . . . . . .

G. Richter, K. Gruhn und Annelore Lemser, Prüfung der Verdaulichkeit der Rohnährstoffe und der Einsatzwürdigkeit von Tapioka bei Legehennen und Nachzucht. . . .

B. K. OGunmodede and S. Leger, Comparative investigations of the diet and nutrient consumption, Feed growth, and nutrient efficiency of broiler chicks under different climatic conditions in Nigeria . . . . . . . . . . . . . . . . .

W. Steffens, Further results of complete replacement of fish meal by means of poultry byproducts meal in feed for trout fry and fingerling (Salmo gairdneri) 

Archives

of Animal Nutrition

Archiv

für Tierernährung

VOLUME 37 • JANUARY 1987 • NUMBER 1

FOUNDED BY ERNST MANGOLD

EDITED BY HANS BERGNER

EDITORIAL BOARD

K. Bođ̆a, Košice

S. Buraczewski, Jablonna

G. Burlacu, Bukarest

D. Demeyer, Gent

B. O. Eggum, Kobenhavn

G. Gebhardt, Leipzig

A. Hennig, Jena

B. Juhász, Budapest

M. Kirchgeßner, Weihenstephan

W. Laube, Rostock

I. Leibetseder, Wien

D. A. Melnitschuk, Kiev
K. H. Menke, Hohenheim

L. P. Milligan, Edmonton

J. G. Morris, Davis

K. Nehring, Rostock

H. J. Oslage, Braunschweig

E. Pfeffer, Bonn

B. Piatkowski, Dummerstorf-Rostock

S. Poppe, Rostock

A. Rerat, Jouy-en-Josas

R. Schiemann, Rostock

N. A. Schmanenkov, Borovsk

A. Schürch, Zürich

R. H. Smith, Shinfield

A. Sommer, Nitra

S. Tamminga, Lelystad

Grete Thorbek, Kobenhavn

\section{AK ADEMIE-VERLAG BERLIN}

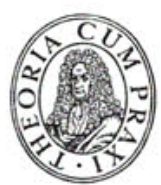


Archives of Animal Nutrition covers the following topics: Blochemical and physiological foundations of animal nutrition with emphasis laid on the following aspscts: Protein matabolism, mstabolism of non-protein-nitrogen compounds, energy traasformation, mineral motabolism, vitamin matabolism, nutritional effects and performance criteria, furthermore: praotical animal feeding, feedstuff theory, feedstuff preservation and feedstuff processing.

W e accept for publication:

Original manuscript not yet published in other journals and not intended for publication in other journals in the same $f$ orm. Their length should not exceed 12 printed pages.

Manuscripts are to be sent to Prof. HANS BERGNER, Wissenschaftsbereich Tierernährung der Sektion Tierproduktion und Veterinărmedizin, Humboldt-Universität zu Berlin, Invalidenstr. 42, Berlin, 1040. We request the authors to submit their manuscripts typed double-spaced and ready for print. The institution which the paper originates will be mentioned together with the author's name in the title of the paper.

The author is requested to discuss and summarize the results of his work at the end of the manuscript.

Author's names in the manuscript are to be underlined with a red wavy line. We request you to underline italica with a black or blue wavy line. Small print is to be indicated by a black or blue vertical line on the nargin. Bibliographic data in the text are given with the name of the author and the year of publication, in case of several publications in one year, a, b, c etc. are added according to the sequence of the publications in the bibliography, e.g. MEYER (1085a). In the bibliography the papers are arranged alphabetically according to the name of the first author and quoted as follows: surname, first name, journal, volume, page and year.

Illustrations have to be restricted to the necessary minimum and to be enclosed separately. Indicative lines, letters etcare to be entered in pencil. For photographes, a cover sheet should be used for this. The captions of the illustrations are to be listed on an extra sheet.

The authors receive 50 special prints of their contributions free of charge.

\section{Terms of Subscription}

Orders for the journal "Archives of Animal Nutrition" can be sent

- in the GDR: to the Postzeitungsvertrieb or to the Akademie-Verlag Berlin, Leipziger Str. 3-4, Berlin, DDR - 1086;

- in the other socialist countries: to a book-shop for foreign language literature or to the competent news-distributing agency;

- in the FRG and Berlin (West): to a book-8hop or to the wholesale distributing agency Kunst und Wissen, Erich Bieber OHG, Wilhelmstr. 4-6, D - 7000 Stuttgart 1;

- in the other Western European countries: to Kunst und Wissen, Erich Bieber GmbH, General Wille-Str. 4, Ch- 8002 Zürich;

- in other countries: to the international book- and journal-selling trade, to Buchexport, Volkseigener Außenhandelsbetrieb der DDR, Postfach 160, Leipzig, DDR - 7010, or to the Akademie-Verlag Berlin, Leipziger Str. 3-4, Berlin, DDR - 1086.

Zeitschrift „Archives of Animal Nutrition“

Herausgeber: Im Auftrag des Akademie-Verlages Berlin herausgegeben von Prof. Dr. Hans Bergner.

Verlag: Akademie-Verlag Berlin, Leipziger Str. 3-4, Berlin, DDR - 1086.

Fernruf: 2236201 oder 2236229 , Telex-Nr.: 114420.

Bank: Staatsbank der DDR, Berlin, Kto.-Nr. 6836-36-20712.

Chefredakteur: Prof. Dr. Bc. Hans Bergner.

Anschrift der Redaktion: Humboldt-Universität zu Berlin, Invalidenstr. 42, Berlin, DDR - 1040.

Verōffentlicht unter der Lizenznummer 1274 des Presseamtes beim Vorsitzenden des Ministerrates der Deutschen Demokratischen Republik.

Gesamtherstellung: VEB Druckerei „Gottfried Wilhelm Leibniz, Gräfenhainichen, DDR - 4450.

Erscheinungsweise: Archives of Animal Nutrition erscheint jährlich in einem Band mit zwölf Heften.

Bezugspreis je Band 360,- DM zuzüglich Versandspesen; Preis je Heft 30,-DM.

Der gültige Jahreshezugspreis für die DDR ist der Postzeitungsliste zu entnehmen.

Bestellnummer dieses Heftes: 1010/37/1.

Urheberrecht: Alle Rechte vorbehalten, insbesondere die der Ubersetzung. Kein Teil dieser Zeitschrift darf in irgendeiner Form - durch Photokopie, Mikrofilm oder irgendein anderes Verfahren - ohne schriftliche Genehmigung des Verlages reproduziert oder in eine von Maschinen, insbesondere von Datenverarbeitungsanlagen verwendbare Sprache übertragen oder übersetzt werden. - All rights reserved (including those of translations into foreign languages). No part of this issue may be reproduced in any form, by photoprint, microfilm or any other means, nor transmitted or translated into a machine language, without written permiseion from the publishers.

(C) 1987 by Akademie-Verlag Berlin - Printed in the German Democratic Republic.

AN (EDV) 39532

02000 